\title{
The Effect of Service Quality and Perceived Price Fairness on Consumer Loyalty through Consumer Satisfaction on Budget Hotel in East Java
}

Christina Esti Susanti*

\author{
Widya Mandala Catholic University, Surabaya, Indonesia; susantiesti@yahoo.com
}

\begin{abstract}
The purpose of this study was to determine and analyze the influence of service quality and perceived price fairness on consumer loyalty through customer satisfaction in budget hotels in East Java. This study of causality research uses a quantitative approach by testing hypotheses. In this study, the data will be tested using statistical formulas and using Structural Equation Modeling (SEM). The type of data in this study is quantitative data. The data source in this study is primary data. Data was obtained from questionnaires filled by budget hotel customers in East Java through surveys by distributing questionnaires to obtain data from respondents. The scale of data measurement used in this study is the interval scale that is one scale with the other scale has the same distance or size. The data measurement tool used is the Likert Scale. The research population refers to consumers who have stayed at budget hotels in East Java. Sampling is done using non probability sampling withdrawal techniques. The sample size in this study was 200 respondents with characteristics: a minimum age of 21 years and had stayed at a budget hotel in East Java at least more than once in the last 6 months. The results of the study prove that, first, service quality has a positive and significant effect on customer satisfaction $(0.87$, t-value 2.78). Second, perceived price fairness has a positive and significant effect on customer satisfaction ( 0.73 with a tvalue of 2.45). Third, customer satisfaction has a positive and significant effect on customer loyalty (0.98 and t value 3.69). Fourth, service quality has a positive and significant effect on customer loyalty through customer satisfaction ( 0.69 and the $\mathrm{t}$-value is 4.04). Fifth, perceived price fairness has a positive and significant effect on customer loyalty through customer satisfaction ( 0.77 and the $t$-value is 2.11 ). Based on these results it can be concluded that if the budget hotel provides quality services and fair prices to its customers, consumers will be satisfied and eventually will be loyal to the budget hotel. Suggestions are proposed for the consumer loyalty theory learning to continue testing variables that affect consumer loyalty apart from the variables examined in this study, namely: service quality, perceived price fairness, consumer satisfaction, and consumer loyalty.
\end{abstract}

Keywords: Consumer Loyalty, Consumer Satisfaction, Perceived Price Fairness, Service Quality

\section{Introduction}

The hotel is a house building that provides services, food, and lodging for guests with a minimum of 6 bedrooms and a minimum of 3 rooms including bathroom facilities. Based on the level of service and facilities provided, hotels can be classified into luxury hotels or economy hotels. Economic hotels are also known as budget hotels that offer clean and tidy rooms. Budget hotels provide alternatives for customers who only need a simple room with a comfortable bed and a clean bathroom. The construction of budget hotels in East Java is very rapid in line with economic growth and tourism, which has caused the level of competition between hotels to be very high.

Xie and Chaipoopirutana ${ }^{1}$ show that the key to hotel success is customer satisfaction. Therefore, hoteliers need to make efforts to differentiate their products and services and increase customer satisfaction. In addition to this, there are still many customers who are worried about their budget. Customers are looking for a budget hotel that is really cheap to stay. Customers also become rational in spending money to get comfortable budget hotel services.

${ }^{\star}$ Author for correspondence 
Service quality according to Wong and Perry ${ }^{2}$ is defined as the perception of the assessment of the results of the evaluation process in which consumers compare their expectations with the services they perceive they will get. Service quality is considered as one of the main driving factors for customer satisfaction recognized as reality.

According to Bei and Chiao ${ }^{\underline{3}}$ the lower the perception of price, the lower the perception of sacrifice for the product. So that consumers will be more satisfied with the perception of prices and the overall transaction carried out. This implies that monetary prices or perceptions of prices not necessarily increase satisfaction. Consumers always associate prices with service quality through the concept of equity, thus creating a level of satisfaction or dissatisfaction with consumers.

In the satisfaction model according to Bei and Chiao, product quality is as important as service quality in influencing customer satisfaction. Service quality, product quality, and price are factors that influence satisfaction. Satisfaction as a result of price, expectations and performance.

Consumer loyalty is often interpreted as buying behavior, in contrast to consumer satisfaction which is an attitude (Wong and $\mathrm{Chou}^{4}$ ). Negative emotions caused by failed services can result in consumer behavior to leave the company. Based on the previous research, it can be said that there is a direct relationship between emotions and consumer loyalty behavior.

The purpose of this study is to test and analyze the influence of: service quality to consumer satisfaction, perceived price fairness to consumer satisfaction, consumer satisfaction to consumer loyalty, service quality to consumer loyalty through consumer satisfaction, and perceived price fairness to consumer loyalty through consumer satisfaction at budget hotels in East Java.

The benefits of this study are theoretically expected to be used as reference material for those who want to conduct research on brand equity specifically regarding the effect of service quality and perceived price fairness on consumer loyalty through consumer satisfaction.

Practically the results of this study are expected to be used as input and consideration for existing hotel budget managers, especially those related to the effect of service quality and perceived price fairness on consumer loyalty through consumer satisfaction.
Based on the research objectives to be achieved in this study, the hypothesis proposed in this study are:

1. Service quality has a significant effect on consumer satisfaction.

2. Perceived price fairness has a significant effect on consumer satisfaction.

3. Consumer satisfaction has a significant effect on consumer loyalty.

4. Service quality has a significant effect on consumer loyalty through consumer satisfaction.

5. Perceived price fairness has a significant effect on consumer loyalty through consumer satisfaction.

\section{Literature Review}

\subsection{Prior Research}

Previous research on the same topic has been carried out by Gumussoy and Koseoglu ${ }^{5}$ in Turkey. The results of this study prove service quality, perceived value, and perceived price fairness has a significant effect on consumer satisfaction. And consumer satisfaction has a significant effect on consumer loyalty.

The second previous study was carried out by Khraim et al. ${ }^{6}$ in Jordan. The results of the study prove that perceived value and customer satisfaction have a significant effect on perceived price fairness.

The third previous research was carried out by Mubiri ${ }^{\mathbb{7}}$ at Lake Kivu Serena Hotel. The results of this study prove that consumer satisfaction has a significant effect on consumer retention.

\subsection{Theoretical Basis}

\subsubsection{Service Quality}

According to Kotler and Armstrong.: "Any Activity or benefit that one party can offer to another is essentially intangible and does not result in ownership of anything". That is, service is offered by one party to another which is intangible and does not produce ownership. As with goods, services that are marketed must also be of high quality. One cannot judge the quality of service before he feels it or consumes it himself. If a consumer buys a service, he only uses, utilizes, or rents the service. The consumers concerned do not necessarily have the services they buy. 
Zeithaml et al., in Naik et al.. stated that "there are many factors can affect customer satisfaction, such as service quality". Service quality is preferred and sought after rather than product quality. The quality of service that is valued by consumers is not only based on the results of service but also included as long as the service is proceeding. For example: how employees communicate and behave during the transaction process. Good service quality will reflect a good picture of the company, besides, if good service quality is truly implemented, it can be used as a way to maintain the company's survival and development.

According to Zeithaml et al., in Naik et al.. "Service quality, as perceived by customers can be defined as the level of difference between customer expectations or desires and their perceptions". The above explains that the quality of services, as perceived by consumers, can be defined as the difference between the desires or expectations of consumers and their perceptions. So the quality of service is a special service or luxurious service that is compared to consumer expectations. In services, quality is a function of consumer perception. In other words, service quality is what consumers feel that relates to meeting consumer needs.

Assessment of the quality or low quality of service depends on how consumers perceive or view the actual service provided by the company. In assessing the service quality of a company, consumers use their perceptions of several quality dimensions. The combination of the assessment of the quality dimension is an overall assessment.

\subsubsection{Perceived Price Fairness}

Zeithaml and Bitner in Bei and Chiao ${ }^{3}$ indicate that the development of satisfaction is broader than the quality of service, but there are also other factors of service quality, product quality, price, situation, and consumer personal factors. From the cognitive concept of consumers, price is something that must be given or sacrificed to obtain a product or service. The lower the price perception, the lower the perception of the sacrifice for the product. So that consumers will be more satisfied with the perception of prices and the overall transaction carried out. This implies monetary prices, or the perception of prices not necessarily increase satisfaction. Consumers always associate prices with service quality through the concept of equity, thus creating a level of satisfaction or dissatisfac- tion with consumers. to get certain types of services or products, customers need to sacrifice prices. Exchange between prices and services / products provided must be considered fair by customers, creating customer satisfaction and fair prices.

Anderson et al., in Bei and Chiao ${ }^{\underline{3}}$ state that prices are an important factor of consumer satisfaction, because after all consumers evaluate the value of services received, they always think about prices. The objective price is not the same as the price that is targeted in the minds of consumers. Consumers define price more than money that must be spent to get goods or services. Therefore, for consumers the price is an important factor in determining satisfaction as a customer because it places prices as the first factor. In general, fair prices are based on customer perceptions of their knowledge of prices set by producers for the market as a whole.

In addition, Zeithaml in Sanghavi ${ }^{10}$ explains that lower price perceptions are associated with lower perceptions of sacrifice. Low prices do not guarantee high customer satisfaction. But often customers place prices as an important consideration for buying certain products or services. According to Bolton et al. $\underline{11}$ the majority of customers have unclear ideas about prices, costs, and profits in the service sector. This lack of knowledge can result in unfair pricing policies, which can be directly related to customer satisfaction. To improve this situation, it is necessary that equity functions be communicated to customers effectively (Choi and Mattila) ${ }^{12}$. In the hospitality industry information about fair prices is delivered by the hotel reservation section at the time of booking by giving instructions on what consumers expect from the hotel. In addition, Bei and $\mathrm{Chiao}^{\underline{3}}$ stated that hotel directors need to pay more attention to customer perceptions about price fairness, because it cannot be denied related to customer satisfaction. In addition, previous research has provided evidence that fairness of prices is related to customer satisfaction and customer behavior intentions (Bolton et al.)ㄹ.

\subsubsection{Consumer Satisfaction}

Bei and Chiao ${ }^{\underline{3}}$ states that consumer satisfaction as a relationship to state psychologically for an assessment between what consumers get by giving. Consumer satisfaction is the result of the purchase and use of products, which are made by consumers to compare the results obtained with the costs of the purchase. Oliver (in Bei 
and Chiao $\mathrm{o}^{\underline{3}}$ defines satisfaction as a statement of total psychology when there is a comparison between emotions and expectations, and as expectations are the feelings of consumers accumulated and collected based on previous purchasing experiences. Zeithaml et al., (in Bei and Chiao) $)^{\underline{3}}$ states service quality, product quality, and price, as factors that influence satisfaction. Voss and Colleagues (in Bei and Chiao) $)^{\frac{3}{3}}$ indicate satisfaction as a result of consumer evaluation of prices, expectations, and performance.

Customer satisfaction has become a popular topic in marketing practices and academic research since the initial study of customer business, expectations and satisfaction. Although there are many attempts to measure and explain customer satisfaction, there seems to be no consensus on the definition (Giese and Cote) ${ }^{13}$. Customer satisfaction is usually defined as a post-consumption evaluative assessment of a particular product or service (Gundersen et al. $)^{\frac{14}{}}$. Satisfaction is the result of an evaluative process that distinguishes prepaid expectations with perceptions of performance during and after the consumption experience. The concept of widely accepted consumer satisfaction is the theory of disconfirmation expectations (Barsky ${ }^{15}$; Oh and Parks ${ }^{16}$; McQuitty et al. ${ }^{17}$ ). This theory was developed by Oliver ${ }^{18}$, who argued that the level of satisfaction is the result of the difference between expected and perceived performance. Satisfaction (positive disconfirmation) occurs when the product or service is better than expected. On the other hand, dissatisfaction (negative confirmation) occurs when performance is worse than expected. Luo and Homburg ${ }^{19}$ concluded that customer satisfaction has a positive effect on business profitability. Most studies have examined the relationship with customer behavior patterns (Kandampully and Suhartanto ${ }^{20}$; Dimitriades ${ }^{21}$; Olorunniwo et al. ${ }^{22}$; Chi and $\mathrm{Qu}^{2} \underline{23}$; Faullant et al. $\left.{ }^{24}\right)$. According to the researchers' findings, customer satisfaction increases customer loyalty, affects repurchase intention, and positive information by word of mouth.

\subsubsection{Consumer Loyalty}

Companies engaged in the service industry use customer loyalty programs to retain their customers. Customer loyalty is not a simple concept. The Oxford dictionary defines loyalty as the right condition of loyalty. But repurchases are interpreted the same as the definition of loyalty mentioned above. In the service domain, loyalty has been defined in broad terms as "observed behavior" (Bloemer et al. ${ }^{25}$ ). Caruana ${ }^{26}$ argues that behavior is an expression of full loyalty to the brand and not just the mind. However, behavioral standards (such as repeat purchases) have been criticized, due to the lack of a conceptual basis for dynamic processes (Caruana $\mathrm{a}^{27}$ ). Therefore, customer loyalty is considered an attitude structure. For example, the tendency to suggest service offers to other customers. Another approach to customer loyalty is the cognitive approach. The operational definition of this approach often refers to the first product or service that comes to mind when making a decision to buy. Meanwhile, in the definition of Ostrowski et al. ${ }^{27}$ and Bloemer et al..$\underline{25}$ referring to the first product or service someone chooses between products and services.

McMullen ${ }^{28}$ states "the long term success of a particular brand is not based on the number of repeat purchasers". Customer loyalty reflects the re-purchase of brands or companies carried out by consumers. Consumers can repurchase a product for many reasons rather than loyal. For example, a cheaper alternative price is easier to produce a repeat purchase. many other consumers can indicate loyalty because there is no alternative. Other consumers may not look for alternatives (it is assumed there are some of them) if other providers cannot meet their expectations. Generalization regarding loyalty cannot be formulated. But there are some common characteristics that can be identified whether consumers approach loyalty or not.

\subsubsection{Research Model}

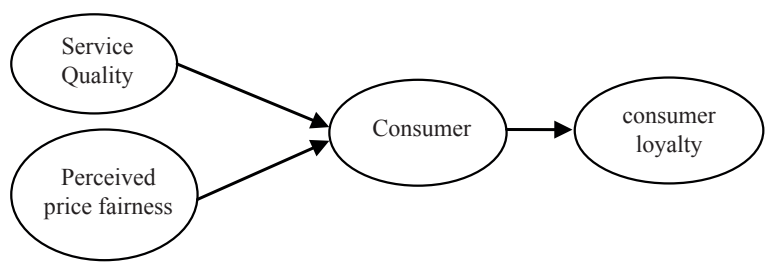

Figure 1. Research model.

Figure 1 demonstrates the research model proposed in this study which illustrates the influence of service quality and perceived price fairness on consumer loyalty through customer satisfaction.

\section{Research Methods}

This study uses a quantitative approach by testing hypotheses. The data measurement tool used was a Likert Scale. 
The research population refers to consumers who have stayed at a budget hotel in East Java. The sampling technique uses judgmental sampling. The sample size in this study were 200 respondents with characteristics minimum age of 21 years and have stayed at a budget hotel in East Java at least more than 1 time in the last 6 months.

The data analysis technique used in this study is Structural Equation Model (SEM).

\section{Results and Discussion}

Table 1 explains loading factor effect of service quality on consumer satisfaction is 0.87 with a $\mathrm{t}$-value of 2.78 ( $>1.96)$ therefore the results are stated to be significant and positive. These results prove that if a budget hotel provides quality services, consumers feel satisfaction with the budget hotel. The results of this study support the previous research conducted by Gumussoy and Koseoglu ${ }^{5}$ in Turkey where the research proves that. service quality, perceived value, and perceived price fairness has a significant effect on consumer satisfaction.

Loading factor of the effect of perceived price fairness on consumer satisfaction is 0.87 with a $t$-value of 2.78 (> 1.96) therefore the results are stated significant and positive. These results prove that if a budget hotel provides a fair price, consumers feel satisfaction with the budget hotel. The results of this study support the previous research conducted by Gumussoy and Koseoglu ${ }^{5}$ in Turkey where the research proves that. service quality, perceived value, and perceived price fairness has a significant effect on consumer satisfaction.

Loading factor influence of consumer satisfaction on consumer loyalty is 0.98 and $t$-value is $3.69(>1.96)$ then the results are stated significant and positive. these results prove that respondents who feel satisfied with the budget hotel also have loyalty to the budget hotel. The results of this study support previous research that has been done by Mubiri ${ }^{7}$ in Lake Kivu Serena Hotel where the research proves that consumer satisfaction has a significant effect on consumer retention.

Loading factor effect of service quality on consumer loyalty through consumer satisfaction is 0.69 and t-value is $4.04(>1.96)$ then the results are stated significant and positive. These results prove that budget hotel visitors who have satisfaction with service quality ultimately have loyalty to the budget hotel. The results of this study support the previous research conducted by Gumussoy and Koseoglu ${ }^{5}$ in Turkey which proves service quality, perceived value, and perceived price fairness have a significant effect on consumer satisfaction and consumer satisfaction have a significant effect on consumer loyalty. Besides that it also supports the second previous research conducted by Mubiri ${ }^{\mathrm{T}}$ at Lake Kivu Serena Hotel where the research proves that consumer satisfaction has a significant effect on consumer retention.

Loading factor influences perceived price fairness to consumer loyalty through consumer satisfaction is 0.77 and $t$-value is $2.11(>1.96)$ then the results are stated significant and positive. These results prove that budget hotel visitors who feel satisfaction with fair prices ultimately have loyalty to the budget hotel. The results of this study support the previous research conducted by Gumussoy and Koseoglu ${ }^{5}$ in Turkey which proves service quality, perceived value, and perceived price fairness have a significant effect on consumer satisfaction and consumer satisfaction have a significant effect on consumer loyalty. Besides that it also supports the second previous research conducted by Mubiri $^{7}$ at Lake Kivu Serena Hotel where the research proves that consumer satisfaction has a significant effect on consumer retention.

Table 1. Hypothesis test results

\begin{tabular}{|l|l|l|l|l|}
\hline $\begin{array}{l}\text { Hypo- } \\
\text { thesis }\end{array}$ & $\begin{array}{l}\text { Pattern of } \\
\text { Relationship }\end{array}$ & $\begin{array}{l}\text { Loading } \\
\text { Factor }\end{array}$ & t-value & Description \\
\hline 1 & $\begin{array}{l}\text { Service quality } \rightarrow \\
\text { Consumer } \\
\text { satisfaction }\end{array}$ & 0.87 & 2.78 & Significant \\
\hline 2 & $\begin{array}{l}\text { Perceived price } \\
\text { fairness } \rightarrow \\
\text { Consumer } \\
\text { satisfaction }\end{array}$ & 0.73 & 2.45 & Significant \\
\hline 3 & $\begin{array}{l}\text { Consumer } \\
\text { satisfaction } \rightarrow \\
\text { Consumer loyalty }\end{array}$ & 0.98 & 3.69 & Significant \\
\hline 4 & $\begin{array}{l}\text { Service quality } \rightarrow \\
\text { Consumer } \\
\text { satisfaction } \rightarrow \\
\text { Consumer loyalty }\end{array}$ & 0.69 & 4.04 & Significant \\
\hline 5 & $\begin{array}{l}\text { Perceived price } \\
\text { fairness } \rightarrow \\
\text { Consumer } \\
\text { satisfaction } \rightarrow \\
\text { Consumer loyalty }\end{array}$ & 0.77 & 2.11 & Significant \\
\hline
\end{tabular}

Source: Data, processed 


\section{Conclusions}

Based on the results of hypothesis testing it can be concluded that hypothesis which states:

1. Service quality has a positive and significant effect on consumer satisfaction at budget hotels in East Java, accepted.

2. Perceived price fairness has a positive and significant effect on consumer satisfaction at budget hotels in East Java, accepted.

3. Consumer satisfaction has a positive and significant effect on consumer loyalty at a budget hotel in East Java, accepted.

4. Service quality has a positive and significant effect on consumer loyalty through consumer satisfaction at budget hotels in East Java, accepted.

5. Perceived price fairness has a positive and significant effect on consumer loyalty through consumer satisfaction at budget hotels in East Java, accepted.

\section{Acknowledgement}

Thank you very much, the researcher conveyed to Widya Mandala Catholic University Surabaya who funded this research.

\section{References}

1. Xie, Jingjing, Chaipoopirutana S. An examination of the influencing factors toward customer satissfaction: Case study of a Five Star Hotel in Bangkok, Thailand. International Conference on Business, Law, and Corporate Social Responsibility (ICBLCSR'14), Phuket. Thailand; 2014.

2. Wong SM, Perry C. Customer service strategies in financial retailing. International Journal of Bank Marketing. 1991; 9(3):11-16. https://doi. org/10.1108/02652329110001882

3. Bei, Ti L, Chiao YC. An integrated model for the effects of perceived product, perceived service quality, and perceived price fairness on consumer satisfaction and loyalty. Journal of Consumer Satisfaction, Dissatisfaction, and Complaining Behavior. 2001;14:125-1140.

4. Wong A, Zhou L, Determinants and outcomes of relationship quality. Journal of International Consumer Marketing. 2006; 18(3):81-105. https://doi.org/10.1300/ J046v18n03_05
5. Gumussoy, Altin C, Koseoglu B. The effects of service quality, perceived value and price fairness on hotel customers' satisfaction and loyalty. Journal of Economics, Business and Management. 2016; 4(9):523-7.

6. Khraim, Salim H, Al-Jabaly SM, Khraim AS. The effect of perceived value and customer satisfaction on perceived price fairness of airline travelers in Jordan. Universal Journal of Management. 2014; 2(5):186-96.

7. Mubiri, Bizi J. Customer satisfaction in hotel services: case - Lake Kivu Serena Hotel. Thesis, School of Service and Business Management. JAMK University of Applied Sciences, Finland; 2016.

8. Kotler, Philip, Armstrong G. Principles of Marketing, 13th Edition. United State of America. Pearson; 2010.

9. Naik, Krishna CN, Gantasala SB, Prabhakar GV. Service quality (Servqual) and its effect on customer satisfaction in retailing. European Journal of Social Sciences. 2010; 16(2):231-43.

10. Punit S. Customer perceptions of fairness in hotel revenue management. Thesis Prepared for the Degree of Master of Science University of North, Texas; 2005.

11. Bolton LE, Warlop L, Alba JW. Consumer perceptions of price (Un)fairness. Journal of Consumer Research. 2003; 29:474-91. https://doi.org/10.1086/346244

12. Choi S, MattilaAS. Hotel revenue management and its impact on customers' perceptions of fairness. Journal of Revenue and Pricing Management. 2014; 2(4):303-14. https://doi.org/10.1057/palgrave.rpm.5170079

13. Giese JL, Joseph A. Cote defining consumer satisfaction. Academy of Marketing Science Review. 2002; 2000(1):1-27

14. Gundersen MG, Heide M, Olsson UH. Hotel guest satisfaction among business travellers: What are the important factors? The Cornell Hotel and Restaurant Administration Quarterly. 1996; 37(2):72-81. https://doi.org/10.1177/001088049603700222

15. Barsky JD. Customer satisfaction in the hotel industry: Meaning and Measurement. Hospitality Research Journal. 1992; 16(1):51-73. https://doi. org/10.1177/109634809201600105

16. Oh H, Parks S. Customer satisfaction and service quality: A Critical review of the literature and research implications for the hospitality industry. Hospitality Research Journal. 1997; 20(3):35-64.

17. McQuitty S, Finn A, Wiley JB. Systematically varying customer satisfaction and its implications for product choice. Academy of Marketing Science Review. 2000; 2000(10):1-18.

18. Oliver RL. A cognitive model of the antecedents and consequences of satisfaction decisions. Journal of Marketing Research. 1980; 17:460-9. https://doi. org/10.2307/3150499 
19. Luo X, Homburg C. Neglected outcomes of customer satisfaction. Journal of Marketing. 2007; 71(2):133-49. https://doi.org/10.1509/jmkg.71.2.133

20. Kandampully J, Suhartanto D. Customer loyalty in the hotel industry: The role of customer satisfaction and image. International Journal of Contemporary Hospitality Management. 2000; 12(6):346-51. https://doi. org/10.1108/09596110010342559

21. Dimitriades ZS. Customer satisfaction, loyalty and commitment in service organizations - some evidence from Greece. Management Research News. 2006; 29(12):782800. https://doi.org/10.1108/01409170610717817

22. Olorunniwo F, Hsu MK, Udo GJ. Service quality, customer satisfaction and behavioural intentions in the service factory. Journal of Services Marketing. 2006; 20(1):59-72. https://doi.org/10.1108/08876040610646581

23. Chi CG-Q, Qu H. Examining the structural relationships of destination image, tourist satisfaction and destination loyalty, an integrated approach. Tourism Management. 2008; 29:624-36. https://doi.org/10.1016/j.tourman.2007.06.007
24. Faullant R, Matzler K, Füller J. The impact of satisfaction image on loyalty: The case of Alpine Ski Resorts. Managing Service Quality. 2008; 18(2):163-78. https://doi. org/10.1108/09604520810859210

25. Bloemer J, De Ruyter K, Wetzels M. Linking perceived service quality, service loyalty: A multi dimensional perspective, European Journal of Marketing, 1999; 33(12):102-6.

26. Caruana A. Service loyalty: The effects of service quality and the mediating role of customer satisfaction. European Journal of Marketing. 2002; 36(8):811-28. https://doi. org/10.1108/03090560210430818

27. Ostrowski PL, O’Brien T, Gordon GL. Service quality and customer loyalty in the commercial airline industry. Journal of Travel Research. 1993; 32(2):16-24. https://doi. org/10.1177/004728759303200203

28. McMullen R. A multiple scale for measuring customer loyalty development. Journal of Service Marketing. 2005; 19(7):47081. https://doi.org/10.1108/08876040510625972 